PACS: $87.14 . \mathrm{Cc}, 87.16 . \mathrm{Dg}$

\title{
APPROACH TO EVALUATE THE RISK OF CANCER FOR DIFFERENT NUMBER OF TUMOR SUPPRESSOR GENES IN THE INDIVIDUAL
}

\author{
M. Bondarenko, V. Knigavko, O. Zaytseva \\ Department of Medical and Biological Physics and Medical Informatics, Kharkiv National Medical University \\ 4 Nauki Ave., Kharkiv, 61022, Ukraine \\ e-mail: bondaren.koma3007@gmail.com \\ Received March 18, 2018
}

Significant progress in understanding the mechanisms of carcinogenesis is associated with the discovery of tumor suppressor genes (or antioncogenes). It is known that in the human population, the number of normally functioning suppressor genes varies in different individuals at birth. The aim of the study was to assess the probability of cancer development in an individual with a different initial number of undamaged normally functioning antioncogenes. On the basis of the probabilistic mathematical model of carcinogenesis, the most probable age of cancer development depending on the number of intact antioncogenes was assessed. As a result of the studies, the probability of cancer development depending on the age of the patient is estimated. The dependence of the probability of cancer development in an individual on the number of undamaged antioncogenes is also investigated. The analysis of the significance of the number of tumor suppressor genes, the damage of which may be the cause of initiation of cell malignancy, has been carried out.

KEYWORDS: tumor suppressor genes, probabilistic mathematical model, carcinogenesis, time of cancer development, genetic mutations, cell genome stability

\section{МЕТОДИКА ОЦЕНКИ ВЕРОЯТНОСТИ РАЗВИТИЯ РАКА ПРИ РАЗЛИЧНОМ КОЛИЧЕСТВЕ ГЕНОВ СУПРЕССОРОВ ОПУХОЛИ У ИНДИВИДА \\ М. Бондаренко, В. Книгавко, О. Зайцева}

Кафедра медиинской и биологической физики и медицинской информатики Харьковский национальный медицинский университет пр. Науки, 4, Харьков, 61022, Украина

Значительный прогресс в понимании механизмов канцерогенеза связан с открытием генов супрессоров опухоли (или антионкогенов). Известно, что в людской популяции у разных индивидов при рождении количество нормально функционирующих генов супрессоров варьирует. Целью работы явилась разработка методики оценки вероятности развития онкозаболевания у индивида при различном исходном количестве у него неповрежденных нормально функционирующих антионкогенов. На основе вероятностной математической модели канцерогенеза проведена оценка наиболее вероятного возраста возникновения онкозаболевания в зависимости от количества неповрежденных антионкогенов. В результате проведенных исследований оценена вероятность возникновения онкозаболевания в зависимости от возраста больного. Исследована также зависимость вероятности возникновения онкозаболевания у индивида от количества имеющихся у него неповрежденных антионкогенов. Проведен анализ значимости количества генов супрессоров опухоли, повреждение которых может быть причиной инициации малигнизации клетки.

КЛЮЧЕВЫЕ СЛОВА: гены супрессоры опухоли, математическая модель, канцерогенез, время образования злокачественной опухоли, генетические мутации, стабильность клеточного генома

\section{МЕТОДИКА ОЦІНКИ ЙМОВІРНОСТІ РОЗВИТКУ РАКУ ПРИ РІЗНІЙ КІЛЬКОСТІ ГЕНІВ СУПРЕСОРІВ ПУХЛИНИ У ІНДИВІДА}

М. Бондаренко, В. Кнігавко, О. Зайцева

Кафедра медичної та біологічної фізики і медичної інформатики

Харківський національний медичний університет пр. Науки, 4, Харків, 61022, Україна

Значний прогрес в розумінні механізмів канцерогенезу пов'язаний 3 відкриттям генів супресорів пухлини (або антионкогенів). Відомо, що в людській популяції у різних індивідів при народженні кількість нормально функціонуючих генів супресорів варіює. Метою роботи є розробка методики оцінки ймовірності розвитку онкозахворювання у індивіда при різній вихідній кількості у нього непошкоджених нормально функціонуючих антионкогенів. На основі ймовірнісної математичної моделі канцерогенезу проведена оцінка найбільш ймовірного віку виникнення онкозахворювання в залежності від кількості непошкоджених антионкогенів. В результаті проведених досліджень оцінено ймовірність виникнення онкозахворювання в залежності від віку хворого. Досліджено також залежність ймовірності виникнення онкозахворювання у індивіда від кількості наявних у нього непошкоджених антионкогенів. Проведено аналіз значущості кількості генів супресорів пухлини, пошкодження яких може бути причиною ініціації малігнізації клітини.

КЛЮЧОВІ СЛОВА: гени супресори пухлини, математична модель, канцерогенез, час утворення злоякісної пухлини, генетичні мутації, стабільність клітинного генома

According to modern ideas about the nature of carcinogenesis, the development of cancer is a complex multi-stage process of accumulation of genetic mutations and other changes in the cell genome that leads to disruption of the basic cellular functions (regulation of proliferation, differentiation, apoptosis, morphogenetic reactions of the cell), and 
leading to ineffective functioning of the antitumor immunity system. Significant progress in understanding the mechanisms of carcinogenesis was associated with the discovery first of oncogenes and protooncogenes, and then genes of tumor suppressors (or antioncogenes). Tumor suppressor genes (TSGs) are cellular genes, the lesion or inactivation of which sharply increases the probability of neoplasm formation, and their function restoration, on the contrary, can suppress the tumor cells growth. TSG structure and expression disorder leads to disturbances in the work of the cell genome control system and antitumor immunity [1-4]. As for congenital anomalies in the system of genetic control, they are a factor that predetermines the inevitable neoplasm development. They increase the probability of occurrence of different carcinogenic mutations in each cell of the body so that sooner or later in one of the cells of the proliferating clone the required set of changes will necessarily accumulate under the selection pressure and a tumor will form. The formation of a tumor becomes only a matter of time [5-15]. It is assumed that initially at birth the number of normally functioning suppressor genes may be different for different individuals and the number is equal to several units; in the modern literature dozens of such genes are described [16-19]. The question about the number of TSGs and their significance in the magnitude of the probability of cancer development is very disputable. Undoubtedly, an important direction in studying the problem of carcinogenesis is a numerical evaluation of both the maximum value of the number of tumor suppressor genes in the cell and the determination of the significance of the number of undamaged antioncogenes in initiating the process of cell malignization.

The purpose of this study was the development of a methodology for assessing the probability of cancer development in an individual with a different initial number of undamaged normally functioning tumor suppressor genes.

\section{RESULTS AND DISCUSSION}

Proceeding from the fact that tumor formation is a probabilistic process, we will use for its description laws and concepts of probability theory. Let's introduce some assumptions and parameters.

Let $\mathrm{N}$ be the maximum number of oncopotent cells in an individual; $\mathrm{k}$ is the initial number of TSGs in an arbitrarily chosen individual.

The values of the parameters $\mathrm{N}$ and $\mathrm{k}$ are unknown a priori, and their estimation is the main problem in constructing the model. In further calculations, we will assume that the duration of the cell cycle is one day (this is typical for the HeLa cell line), and the probability of mutational damage of one tumor suppressor gene in one act of division is $10^{-5}$ [20].

At given values of $\mathrm{N}$ and $\mathrm{k}$, the values of the most probable age, as well as the average age of the individual in which cancer can develop, can be calculated and thereby an acceptable correct estimate of these ages can be obtained. But since the numerical values of the parameters $\mathrm{N}$ and $\mathrm{k}$ are unknown, in this paper we discuss only the methodology of estimating the probability of cancer developing at a certain age at a different number of undamaged normally functioning TSGs.

In our previous studies [21], a probabilistic mathematical model was constructed that makes it possible to calculate the most probable age $(\tau)$ of the individual, in which the cancer develops, depending on the number (k) of TSGs present in the cells. Equation for calculation this age was solved in numerical terms and has the form

$$
\left(1-\left(1-\xi^{-\frac{\tau}{\mathrm{T}}}\right)^{\mathrm{k}}\right)\left(\mathrm{k} \xi^{-\frac{\tau}{\mathrm{T}}}-1\right)=(\mathrm{N}-1) \mathrm{k}\left(1-\xi^{-\frac{\tau}{\mathrm{T}}}\right)^{\mathrm{k}} \cdot \xi^{-\frac{\tau}{\mathrm{T}}}
$$

where $\mathrm{T}$ is duration of one cycle of cell division; $\xi=\frac{1}{1-\alpha}, \alpha-$ the probability of damaging one TSG in one division cycle.

Let, for example, the maximum value of number $\mathrm{N}=1,5 \cdot 10^{6}$ [20], and the maximum value of number $\mathrm{k}=8$. Then the dependence of the values of the most probable age of the individual, in which the cancer develops, on the values of the parameter $\mathrm{k}$ has the form shown in Figure 1.

As can be seen from the graph, the greater the number of undamaged TSGs present in an individual, the greater the probability that he/she will develop cancer at a later age. Cases in which $\mathrm{k}=1$ and 2 are too unlikely for oncological disease to occur. Cases in which $\mathrm{k}=7$ and 8 correspond to an age of more than 100 years, which is not taken into account in the statistical data on the cancer incidence.

Figure 2 shows the dependence of the probability of cancer development on the age of the individual. Data on the number of $n=8288$ cancer patients were obtained in the archive of the S.P. Grigoryev Kharkov Institute of Medical Radiology.

We compared the results of the study presented in Figures 1 and 2. Knowing the most probable age (t) for the cancer development in individuals for various numbers of intact TSGs (k), using data on the probability (p) of oncological disease development depending on the age of the patient, the probability of cancer development in the individual at the corresponding value of TSGs number $(\mathrm{k})$ can be determined. 


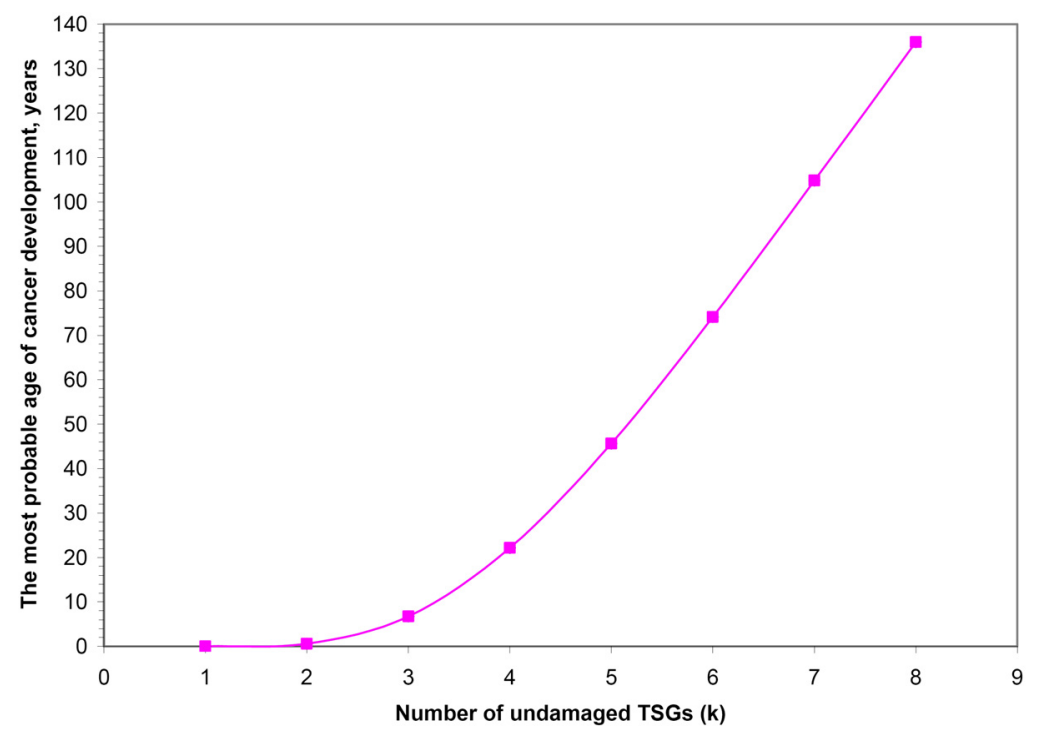

Fig. 1. Dependence of the most probable age of the individual in which the cancer develops on the number (k) of undamaged TSGs

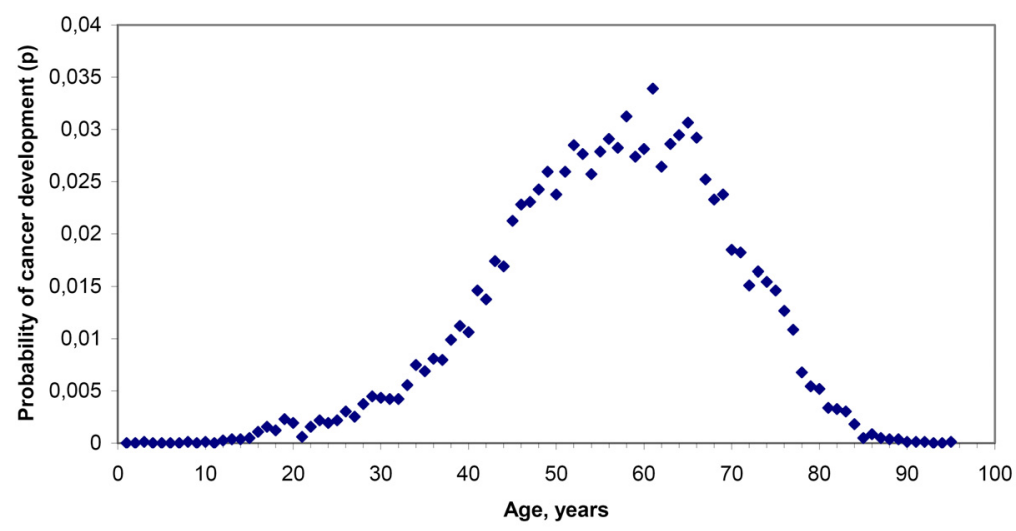

Fig. 2. Probability (p) of cancer development depending on the age of the patient

Figure 3 shows the graph of the probability (p) of cancer development in an individual, depending on the number (k) of his/her undamaged TSGs.

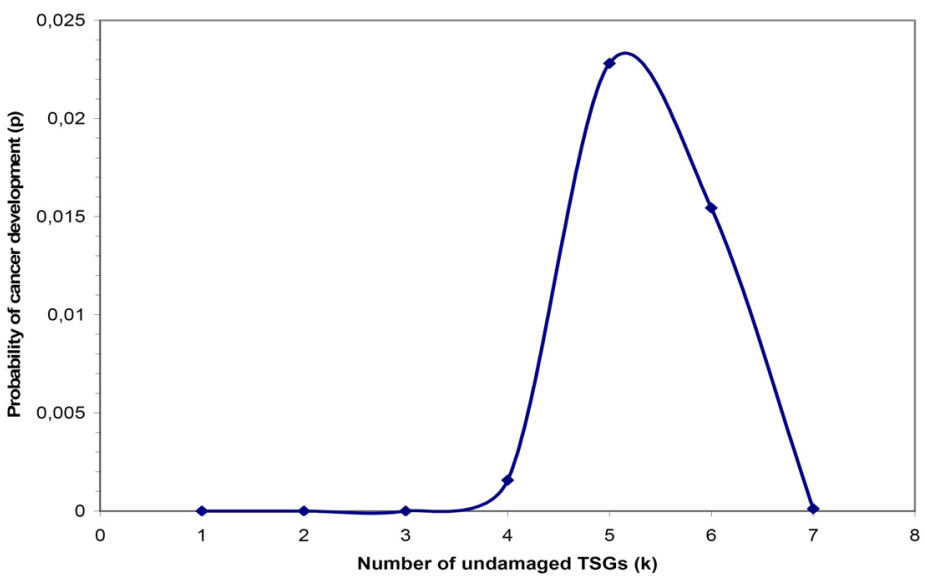

Fig. 3. Dependence of the probability (p) of cancer development in an individual on the number (k) of intact TSGs.

It can be seen from the graph that the probability of cancer development at $\mathrm{k} \leq 3$ and $\mathrm{k} \geq 7$ are practically equal to zero. Thus, the contributions of these numbers of undamaged TSGs to the general distribution can be neglected.

Suppose that for the values of the number of undamaged TSGs equal to $k=4 ; 5$ and 6 , the quantities $\mathrm{P}_{4}, \mathrm{P}_{5}$ and $\mathrm{P}_{6}$ are the probabilities of cancer development at a given age at the corresponding values of $k=4 ; 5$ and 6 . Since the 
events under consideration with the indicated probability values do not form a complete group of events, then to calculate the true values of $\mathrm{P}_{4}, \mathrm{P}_{5}$ and $\mathrm{P}_{6}$ they need to be normalized by one. As a result of the normalization the following values of the required probabilities are obtained:

$$
\mathrm{P}_{4}=0.039394 ; \mathrm{P}_{5}=0.572727 ; \mathrm{P}_{6}=0.387879 \text {. }
$$
and 6.

Thus the following numbers of undamaged TSGs are the significant quantities for cancer developing: $\mathrm{k}=4 ; 5$

Of course, further studies may require a significant correction of the values of both the parameter $\mathrm{N}$ and the parameter $\mathrm{k}$. In addition, the accuracy of the method for assessing the probability of cancer development at a different number of intact TSGs based on the calculation of the most probable age of oncology development depends on the volume of statistical data.

\section{CONCLUSIONS}

1. The estimation of the most probable age of the individual in which the oncological disease occurs is performed, depending on the number of intact TSGs present in individual.

2. On the basis of experimental data, the probability of cancer development depending on the patient's age is analyzed.

3. The dependence of the probability of cancer development in an individual on the number of intact TSGs present in individual is studied.

4. The analysis of the significance of the number of TSGs, the damage of which may cause initiation of cell malignancy, has been carried out.

5. A methodology for estimation of probability of cancer development in an individual at a different number of intact TSGs has been developed.

\section{REFERENCES}

1. Kopnin B.P., Kopnin P.B., Khromova N.V., Agapova L.S. Many-faced p53: a variety of forms, functions, a tumor of suppressive and oncogenic activities // Klinicheskaja onkogematologija [Clinical oncohematology]. - 2008. - Vol. 5. - No.1. P. 3-10. (in Russian)

2. Kopnin B.P. Targets of oncogenes and tumor suppressors: the key to understanding the basic mechanisms of carcinogenesis // Biokhimija [Biochemistry]. - 2000. - Vol.6. - Iss. 1. - P. 5-33. (in Russian)

3. Palijchuk O.V., Polischuk L.Z. Ovarian cancer: familial cancer syndrome and clinical significance of mutation testing in the BRCA1 and BRCA2 genes // Onkologija [Oncology]. - 2016. - Vol. 18. - No. 1. - P. 20-26. (in Russian)

4. Abelev G.I. Immunology of human tumors // Priroda [Nature]. - 2000. - No. 2. - P. 20-25. (in Russian)

5. Clark M., Beker M. Cancer stem cells // V mire nauki [In the world of science]. - 2006. - No. 10. - P. 29-35. (in Russian)

6. Rechkunova N.I., Lebedeva N.A., Lavrik O.I. Tyrosyl-DNA-phosphodiesterase 1 is a new participant in the repair of apurine / apyrrimidine sites in DNA // Bioorganicheskaja himija [Bioorganic chemistry]. - 2015. - Vol. 41. - No. 5. - P. 531. (in Russian)

7. Kipen V.N., Snytkov E.V., Melnov S.B. The role of XRCC1, XRCC3 and PALB2 genes in the genesis of breast cancer // Ekologicheskij vestnik [Ecological bulletin]. - 2015. - No. 1 (31). - P.57-63. (in Russian)

8. Knudson A.G. Antioncogenes and human cancer // Proc. Natl. Acad. Sci. USA. - 1993. - Vol. 90(23). - P. 10914-10921.

9. Young-Sam Keum. Regulation of Nrf2-Mediated Phase II Detoxification and Anti-oxidant Genes // Biomolecules and Therapeutics (Seoul). - 2012.- Vol. 20(2). - P. 144-151.

10. Li W., Kong A.N. Molecular mechanisms of Nrf2-mediated antioxidant response // Mol. Carcinog. - 2009. - Vol. 48. P. 91-104.

11. Vogelstein B., Kinzler K. W. Cancer genes and the pathways they control // Nat. Med. - 2004. - Vol.10. - P. 789-799.

12. Sharpless N.E., Depinho R.A. The mighty mouse: genetically engineered mouse models in cancer drug development // Nat. Rev. Drug Discov. - 2006. - Vol. 5. - P.741-754.

13. Hanahan D., Weinberg R.A. The hallmarks of cancer // Cell. - 2000. - Vol. 100. - P.57-70.

14. Hanahan D. Weinberg R.A. Hallmarks of cancer: the next generation // Cell. - 2011. - Vol. 144. - P. 646-674.

15. Van Der Flier L, Clevers H. Stem cells, self-renewal, and differentiation in the intestinal epithelium // Annual Review of Physiology. - 2009. - Vol. 71. - P.241-260.

16. Rodriguez-Brenes I.A., Komarova N.L., Wodarz D. Cancer-associated mutations in healthy individuals: assessing the risk of carcinogenesis // Cancer Research. - 2014. - Vol. 74(6). - P.1661-1669.

17. Zheng Z.C., Wang Q.X., Zhang W., Zhang X.H., Huang D.P. A novel tumor suppressor gene NCOA5 is correlated with progression in papillary thyroid carcinoma // Onco Targets Ther. - 2018. - Vol. 11. - P. 307-311.

18. TSGene 2.0: an updated literature-based knowledgebase for tumor suppressor genes // Nucleic Acids Res. - 2016. - Vol. 44. P. 1023-1031.

19. Gohlke BO, Nickel J, Otto R, Dunkel M, Preissner R. CancerResource-updated database of cancer-relevant proteins, mutations and interacting drugs // Nucleic Acids Res. - 2016. - Vol. 44. - P. 932-937.

20. Harvey Lodish, Arnold Berk, S Lawrence Zipursky, Paul Matsudaira, David Baltimore, James Darnell. Molecular Cell Biology. Ch.24. - New York: W. H. Freeman, 2000. - 726 p.

21. Knigavko V.G., Radzishevskaja E.B., Bondarenko M.A. Mathematical modeling of carcinogenesis // Biofizychnyj visnyk [Biophysical bulletin]. - 2010. - No. 25(2). - P. 93-100. (in Russian) 